\title{
Strategi PIGELTIK Menuju Sekolah Adiwiyata di SMP Negeri 4 Bobotsari Purbalingga
}

\section{Miswadi Warsono}

SMP Negeri 4 Bobotsari

miswadi.warsono@gmail.com

\section{Article History}

accepted 01/12/2020

approved 01/01/2021

published 01/03/2021

\begin{abstract}
Garbage is a serious problem in schools because students'-low-awareness of disposing garbage is the major factor. Even though trash bins have been provided in each class, students still littering. With the PIGELTIC strategy, the caring attitude of the citizens of SMP Negeri 4 Bobotsari towards the environment increases and the character of students can be formed. School can be clean, beautiful, healthy, and fun and also can lead to be Adiwiyata school.
\end{abstract}

Keywords: Garbage, strategy, PIGELTIC, school, adiwiyata

\section{Abstrak}

Sampah merupakan masalah yang serius di sekolah karena kesadaran siswa yang masih rendah dalam membuang sampah menjadi faktor utama. Walaupun sudah disediakan tempat sampah di masing-masing kelas, namun siswa masih membuang sampah sembarangan. Dengan strategi PIGELTIK maka sikap peduli warga SMP Negeri 4 Bobotsari terhadap lingkungan meningkat dan karakter peserta didik dapat dibentuk. Sekolah menjadi bersih, indah, sehat dan menyenangkan serta dapat menuju sekolah adiwiyata.

Kata kunci: Sampah, strategi, PIGELTIK, sekolah, adiwiyata

Social, Humanities, and Education Studies (SHEs): Conference Series https://jurnal.uns.ac.id/shes 


\section{PENDAHULUAN}

Sampah merupakan masalah yang serius di sekolah. Kesadaran siswa yang masih rendah dalam membuang sampah menjadi faktor utama. Walaupun sudah disediakan tempat sampah di masing-masing kelas, namun siswa masih membuang sampah sembarangan. Lingkungan sekolah menjadi kotor karena sampah berserakan, bahkan laci meja di kelas berubah menjadi tempat sampah yang penuh dengan sampah. Himbauan sekolah kepada siswa untuk tidak membuang sampah sembarangan sering dilakukan, namun siswa hanya merespon seketika itu saja selama masih ada gurunya dan setelah itu membuang sampah sembarangan lagi.

Sekolah sebagai suatu lembaga yang digunakan untuk kegiatan belajar mengajar antara pendidik dan peserta didik. Sekolah menjadi salah satu tempat untuk mendidik peserta didik dengan maksud untuk memberikan ilmu pengetahuan agar menjadi anak- anak yang berguna bagi nusa dan bangsa. Di sekolah inilah peserta didik akan mendapatkan pengetahuan, ketrampilan dan pengalaman sebagai bekal kehidupan yang akan datang. Untuk itu kondisi sekolah harus bersih, rapi, indah, nyaman dan menyenangkan agar menunjang proses belajar mengajar. Pendidikan karakter peserta didik akan terbentuk dengan membudayakan hidup bersih dan peduli lingkungan.

SMP Negeri 4 Bobotsari merupakan sekolah pinggiran yang memiliki latar belakang masyarakat yang menengah bawah dan berpendidikan masih rendah. Hal ini berpengaruh kepada kebiasaan peserta didik dalam berperilaku hidup bersih. Kesadaran warga sekolah terhadap kebersihan lingkungan masih sangat rendah, sehingga sekolah kelihatan kotor dan masih banyak sampah berserakan. Pedagang sekolah seenaknya memberikan bungkus makanan tanpa memperhatikan bungkus makanan mau dibuang kemana. Guru dan tenaga kependidikan masih banyak yang acuh untuk mengingatkan peserta didik dalam membuang sampah. Peserta didik membuang sampah sembarangan, walaupun sudah ada tong sampah di depan kelas dan di setiap sudut sekolah. Hal inilah yang membuat SMP Negeri 4 Bobotsari menjadi sekolah yang kotor dan penuh dengan sampah.

Upaya yang dilakukan sekolah dalam menangani masalah sampah yaitu dengan memberikan pengertian kepada peserta didik dan warga sekolah melalui upacara, rapat, jam perwalian dan sisipan jam pelajaran. Namun upaya tersebut belum berhasil. Sehingga Kepala Sekolah, urusan 7K dan beberapa guru dan tenaga kependidikan mengadakan "gendu-gendu rasa" untuk mencari solusi yang pada akhirnya ditemukan yaitu Strategi Piring Gelas Plastik (PIGELTIK).

Strategi PIGELTIK adalah suatu strategi sekolah dengan cara menggerakkan siswa untuk membawa piring dan gelas plastik. Artinya siswa boleh membeli jajanan di warung sekolah apabila membawa piring dan gelas plastik, bagi siswa yang tidak membawa piring dan gelas palstik tidak diperbolehkan untuk jajan. Tujuan pigeltik adalah untuk mencegah atau mengurangi volume sampah di sekolah. Hal ini sesuai prinsip 3R (Reduce, Reuse, Recycle) Reduce berarti mengurangi, Reuse menggunakan kembali dan Recyle mendaur ulang. Strategi PIGELTIK termasuk dalam prinsip Reduce yaitu mencegah atau mengurangi sampah.

Adapun langkah - langkah dalam menerapkan strategi PIGELTIK adalah Pertama Kepala Sekolah mensosialisasikan kepada seluruh warga sekolah tentang strategi pigeltik dalam amanat upacara bendera. Kedua urusan 7K bersama wali kelas memerintahkan kepada siswa untuk membawa piring dan gelas plastik. Ketiga Kepala Sekolah bersama Urusan 7K mengumpulkan para pedagang di sekolah untuk diberikan pengarahan tentang pigeltik dan keharusan menjaga kebersihan sekolah. Keempat Kepala sekolah memerintahkan kepada wali kelas dan 7K untuk mendata siswa yang memiliki piring dan gelas plastik. Bagi yang sudah memiliki maka dapat membawa piring dan gelas plastik yang sudah ada di rumah, namun jika belum 
memiliki dapat memesan kepada koperasi sekolah. Kelima Koperasi sekolah menyediakan piring dan gelas plastik sesuai data siswa yang belum memiliki.

Untuk memastikan strategi PIGELTIK tetap berjalan, maka harus dilakukan pemantauan dan kontrol secara terus menerus. Pedagang sekolah merupakan kunci keberhasilan dari strategi pigeltik. Komitmen pedagang sekolah sangat dibutuhkan, artinya pedagang hanya melayani siswa yang mau jajan dengan membawa piring dan gelas plastik. Jika pedagang melayani atau memberikan kelonggaran kepada siswa yang tidak membawa piring dan gelas plastik untuk jajan, maka hari berikutnya siswa pasti tidak membawa piring dan gelas plastik. Pada akhirnya siswa banyak yang tidak membawa piring dan gelas plastik.

Pedagang sekolah juga dihimbau untuk menjual jajanan yang sehat dan tidak menggunakan plastik. Jika terpaksa dalam jajanan tersebut dibungkus plastik maka ketika memberikan jajanan kepada siswa, bungkus plastiknya diambil pedagang sekolah dan dikumpulkan di tempat sampah yang ada di kantin. Siswa menerima jajanan di piring dan gelas plastik sudah tidak dibungkus plastik. Setelah selesai makan, piring dan gelas plastik bisa dicuci di sekolah atau di rumah, sekaligus untuk melatih siswa supaya tanggung jawab. Setiap hari siswa membawa kembali piring dan gelas plastik jika ingin jajan di sekolah.

Dengan menerapakan strategi PIGELTIK, diharapkan SMP Negeri 4 Bobotsari menjadi bersih, indah, sehat dan menyenangkan. Ruang kelas yang bersih menjadikan siswa betah belajar di kelas dan proses belajar mengajar semakin menyenangkan. Lingkungan sekolah yang bersih dapat menjaga kesehatan warga sekolah. Sekolah dapat bercita-cita untuk meningkatkan statusnya menjadi Sekolah Sehat ataupun Sekolah Adiwiyata. Penulis meyakini bahwa dengan penerapan Strategi PIGELTIK di SMP Negeri 4 Bobotsari akan menghasilkan yang baik berupa sekolah yang bersih, indah, sehat dan menyenangkan.

Adapun tujuan penulisan best practice ini adalah untuk mendiskripsikan cara penerapan Strategi PIGELTIK dalam mewujudkan SMP Negeri 4 Bobotsari menjadi sekolah adiwiyata dan hasil penerapan Strategi PIGELTIK dalam mewujudkan SMP Negeri 4 Bobotsari menjadi sekolah adiwiyata

\section{Strategi}

\section{HASIL DAN PEMBAHASAN}

Strategi berasal dari bahasa latin "Strategia" yang diartikan sebagai seni penggunaan rencana untuk mencapai tujuan. Strategi adalah kerangka yang membimbing dan membimbing dan mengendalikan pilihan - pilihan yang menetapkan sifat dan arah suatu organisasi perusahaan. Sedangkan menurut Drucker (dalam Berlian 2003:45) Strategi adalah mengerjakan sesuatu yang benar (doing the right things). Sejalan dengan pendapat Clausewitz (dalam wahyudi 1996:16) bahwa strategi merupakan suatu seni menggunakan pertempuran untuk memenangkan perang. Menurut Skinner strategi merupakan filosofi yang berkaitan dengan alat untuk mencapai tujuan.

Hayes dan Weel Wright mengemukakan bahwa strategi mengandung arti semua kegiatan yang ada dalam lingkup perusahaan, termasuk di dalamnya pengalokasian semua sumber daya yang dimiliki perusahaan. Pendapat lain yaitu Hill (dalam Rangkuti, 2000:56), strategi merupakan suatu cara yang menekankan hal - hal yang berkaitan dengan kegiatan manufaktur dan pemasaran.

Dari pengertian diatas maka strategi dapat diartikan sebagai seni dalam melaksanakan perencanaan dalam mencapai tujuan dengan menggunakan sumber daya dan sumber dana yang ada, agar pelaksanaan berjalan secara efektif dan efsien namun mendapatkan hasil yang maksimal. 


\section{Piring Gelas Plastik}

Piring adalah alat makan yang berbentuk datar dan juga ada yang sedikit cekung dimana makanan disajikan. Piring biasanya terbuat dari kaca, porselen, batu, plastik, logam, tanah liat, melamin, kertas, styrofoam, kayu, rotan dan lain-lain. Pada umumnya fungsi piring adalah untuk menampung, baik benda ataupun makanan seperti kue, lauk, sayur, ataupun nasi. Dilihat dari segi ukurannya ada piring kecil, piring tanggung, pring makan dan piring besar. Dilihat dari bentuknya, piring berbentuk bulat, lonjong dan kotak.

Gelas adalah tempat atau alat atau benda yang biasanya digunakan untuk menampung air atau cairan untuk diminum. Gelas adalah benda yang transparan, lumayan kuat, biasanya tidak bereaksi dengan bahan kimia dan tidak aktif secara biologi yang bisa dibentuk dengan permukaan yang sangat halus dan kedap air. Plastik berasal dari (baha Latin) plasticus = mudag dibentuk. Plastik bagian dari polimer termoplastik, yaitu polimer yang akan melunak apabila dipanaskan dan dapat dibentuk sesuai pola yang kita inginkan. Seteleh dingin polimer ini akan mempertahankan bentuknya yang baru. Dari pengertian diatas maka pengertian piring gelas palstik adalah alat yang digunakan untuk makan dan minum yang terbuat dari bahan plastik yang memiliki bentuk dan ukuran yang berbeda

\section{Sekolah}

Sekolah adalah sistem interaksi sosial suatu organisasi keseluruhan terdiri atas interaksi pribadi terkait bersama dalam suatu hubungan organik (Wayne dalam buku Soebagio Atmodiwiro, 2003:37). Sedangkan berdasarkan undang - undang no 2 tahun 1989 sekolah adalah satuan pendidikan yang berjenjang dan berkesinambungan untuk menyelenggarakan kegiatan belajar mengajar.

Menurut Daryanto (1997:554), sekolah adalah bangunan atau lembaga untuk belajar serta tempat menerima dan memberi pelajaran. Zanti Arbi dalam buku Made Pidarta, 1997: 171) mendefinisikan sekolah adalan suatu lembaga atau tempat untuk belajar seperti membaca, menulis dan belajar untuk berperilaku yang baik. Sekolah juga merupakan bagian integral dari suatu masyarakat yang berhadapan dengan kondisi nyata yang terdapat dalam masyarakat pada masa sekarang. Sekolah juga merupakan lingkungan kedua tempat anak-anak berlatih dan menumbuhkan kepribadian.

\section{Adiwiyata}

Berdasarkan peraturan yang mengatur program Adiwiyata adalah Peraturan Menteri Lingkungan Hidup Nomor 02 Tahun 2009 tentang pedoman pelaksanaan program Adiwiyata pasal 1 ayat 1 dan 2, yang dimaksud adiwiyata adalah sekolah yang baik dan idela sebagai tempat memperoleh segala ilmu pengetahuan dan berbagai norma serta etika yang dapat menjadi dasar manusia menuju terciptanya kesejahteraan hidup dan cita-cita pembanguna berkelanjutan. Program Adiwiyata adalah salah satu program kerja berlingkup nasional yang dikelola oleh Kementerian Negara Lingkungan Hidup dalam rangka mewujudkan pengembangan pendidikan lingkungan hidup.

Menurut Widiyaningrum program sekolah Adiwiyata bertujuan untuk menanamkan kecintaan warga sekolah pada lingkungan hidupnya, termasuk menanamkan sikap dna perilaku yang peduli dan berbudaya lingkungan. Wujud kepedulian sekolah tercermin dari upaya warga sekolah mewujudkan pengelolaan lingkungan sekolah dengan prinsip-prinsip ramah lingkungan. Warga sekola adalah mulai dari Kepala Sekolah, Guru, Seluruh siswa-siswi, petugas kebersihan, petugas keamanan dan Komite Sekolah.

Dari beberapa pengertian diatas maka dapat diambil kesimpulan bahwa Pengertian dari program adiwiyata yaitu suatu program pendidikan yang dilakukan 
dengan menerapkan kepedulian terhadap lingkungan dengan cara semua warga di sekolah diminta untuk memiliki perilaku peduli terhadap lingkungan sekolah, serat menerakan sistem pembelajaran yang lebih ditekankan pada pembelajaran terkait dengan lingkungan sekitar.

Untuk penelitian yang relevan yang membahas tentang sekolah adiwiyata penulis menemukan beberapa penelitian yang berkaitan dengan diantaranya adalah Pertama, tesis yang ditulis oleh Ahmad Baihaqi dalam tesisnya yang berjudul "Manajemen Strategik dalam Pengembangan Madrasah Adiwiyata di MTs Negeri 6 Ponorogo”. Hasil penelitian menunjukkan bahwa strategi formulasi yang disusun adalah 1) Kebijakan berwawasan lingkungan, 2) Kebijakan alokasi dana, 3) Kebijakan penyisipan wawasan lingkungan kedalam mata pelajaran, 4) Kebijakan kurikulum berbasis lingkungan, 5) Kebijakan terhadap perubahan Visi, Misi dan tujuan Madrasah. Adapun strategi implementasi yang dilaksanakan adalah 1) Kebijakan peringatan kalender lingkungan hidup, 2) Kebijakan dalam mengelola dan mendukung fasilitas yang ramah lingkungan, 3) Kebijakan kemitraan dalam pengembangan pendidikan untuk menunjang program Adiwiyata, 4) Kebijakan dalam ikut andil dalam kegiatan peduli lingkungan yang ada di luar sekolah. Selanjutnya strategi evaluasi yang dilakukan adalah 1) menentukan standar penilaian dan 2) mengambil tindakan perbaikan.

Kedua, tesis yang ditulis oleh Robingaenah dengan judul : "Manajemen Madrasah Berbasis Adiwiyata di Madrasah Aliyah Negeri 1 Cilacap". Hasil penelitian diperoleh bahwa Manajemen Madrasah Berbasis Adiwiyata di MAN 1 Cilacap dilaksanakan dengan komponen Adiwiyata yaitu :1) Kebijakan Berwawasan Lingkungan; 2) Pelaksanaan Kurikulum Berbasis Lingkungan; 3) Kegiatan Lingkungan Berbasis Partisipatif; 4) Pengelolaan Sarana Pendukung Ramah Lingkungan melalui fungsi manajemen Perencanaan, Pengorganisasian dan Pelaksanaan, Pengawasan dan evaluasi. Hasil dari program Adiwiyata selain predikat menuju Adiwiyata Nasional adalah dililihat dari perilaku atau karakter positif yaitu sikap peduli dan cinta lingkungan semakin tampak.

\section{Metode Pemecahan Masalah}

Upaya yang dilakukan sekolah dalam menangani masalah sampah yaitu dengan memberikan pengertian kepada peserta didik dan warga sekolah melalui upacara, rapat, jam perwalian dan sisipan jam pelajaran. Namun upaya tersebut belum berhasil. Sehingga Kepala Sekolah, urusan 7K dan beberapa guru dan tenaga kependidikan mengadakan "gendu-gendu rasa" untuk mencari solusi yang pada akhirnya ditemukan yaitu Strategi Piring Gelas Plastik (PIGELTIK).

Strategi PIGELTIK adalah suatu strategi sekolah dengan cara menggerakkan siswa untuk membawa piring dan gelas plastik. Artinya siswa boleh membeli jajanan di warung sekolah apabila membawa piring dan gelas plastik, bagi siswa yang tidak membawa piring dan gelas palstik tidak diperbolehkan untuk jajan. Tujuan pigeltik adalah untuk mencegah atau mengurangi volume sampah di sekolah. Hal ini sesuai prinsip 3R (Reduce, Reuse, Recycle) Reduce berarti mengurangi, Reuse menggunakan kembali dan Recyle mendaur ulang. Strategi PIGELTIK termasuk dalam prinsip Reduce yaitu mencegah atau mengurangi sampah.

Adapun langkah - langkah dalam menerapkan Strategi PIGELTIK adalah.

1. Pertama Kepala Sekolah mensosialisasikan kepada seluruh warga sekolah tentang strategi pigeltik dalam amanat upacara bendera. 


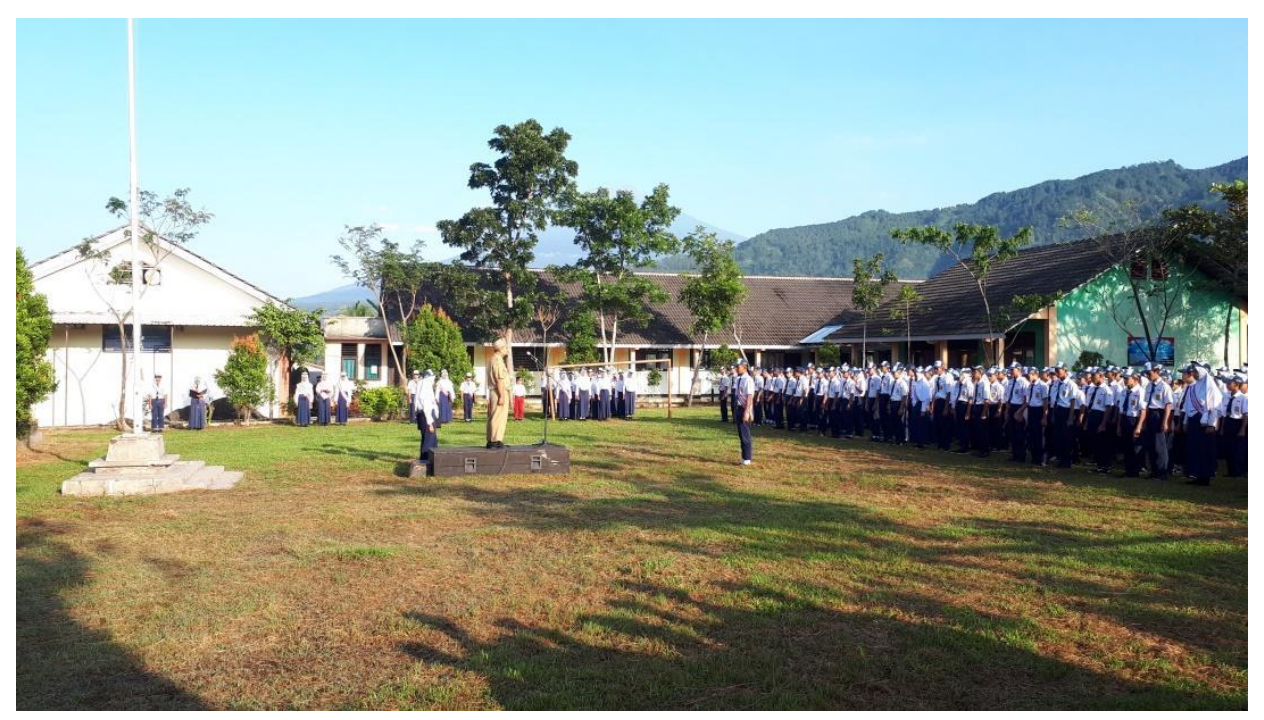

Gambar 1. Kepala Sekolah Mensosialisasikan Strategi Pigeltik Dalam Upacara Bendera

Pada gambar 1, Kepala Sekolah mensosialisasikan kepada seluruh warga sekolah tentang strategi pigeltik dalam amanat upacara bendera. Hal ini dilakukan agar seluruh warga sekolah memiliki kepedulian terhadap lingkungan dengan cara menjaga kebersihan lingkungan. Kepala sekolah menjelaskan kepada semua warga sekolah tentang strategi PIGELTIK yang akan dilaksanakan di SMP Neeri 4 Bobotsari. Dengan prinsip Reduce (mengurangi) yang berarti menguragi/mencegah timbulnya sampah lebih baik daripada mendaur ulang sampah atau memanfaatkan sampah. Hal ini karena keterbatasan peralatan dalam mendaur ulang sampah atau kemampuan memanfaatan barang bekas.

2. Urusan $7 \mathrm{~K}$ bersama wali kelas memerintahkan kepada siswa untuk membawa piring dan gelas plastik. Urusan 7K dan walikelas menjadi penggerak utama dalam mensuksekan strategi PIGELTIK.

3. Kepala Sekolah bersama Urusan 7K mengumpulkan para pedagang di sekolah untuk diberikan pengarahan tentang pigeltik dan keharusan menjaga kebersihan sekolah. Pedagang sekolah merupakan pihak yang berkaitan langsung dengan peserta didik ketika membeli jajan. Perlu penekanan bahwa pedagang sekolah harus dapat bekerja sama dengan sekolah dalam menjaga kebersihan sekolah. Jangan sampai pedagang sekolah melindungi/menutupi peserta didik yang tidak membawa PIGELTIK namun tetap dilayani dikarenakan pedagang sekolah mendapat keuntungan. Ini merupakan kunci keberhasilan strategi PIGELTIK ditangan pedagang sekolah.

4. Kepala sekolah memerintahkan kepada wali kelas dan $7 \mathrm{~K}$ untuk mendata siswa yang memiliki piring dan gelas plastik. Bagi yang sudah memiliki maka dapat membawa piring dan gelas plastik yang sudah ada di rumah, namun jika belum memiliki dapat memesan kepada koperasi sekolah.

5. Koperasi sekolah menyediakan piring dan gelas plastik sesuai data siswa yang belum memiliki. Koperasi siswa sifatnya hanya membantu peserta didik dalam melaksanakan program sekolah dan sifatnya tidak wajib membeli di koperasi.

Untuk memastikan strategi "Pigeltik" tetap berjalan, maka harus dilakukan pemantauan dan kontrol secara terus menerus. Pedagang sekolah merupakan kunci keberhasilan dari strategi pigeltik. Komitmen pedagang sekolah sangat dibutuhkan, artinya pedagang hanya melayani siswa yang mau jajan dengan membawa piring dan gelas plastik. Jika pedagang melayani atau memberikan kelonggaran kepada siswa 
yang tidak membawa piring dan gelas plastik untuk jajan, maka hari berikutnya siswa pasti tidak membawa piring dan gelas plastik. Pada akhirnya siswa banyak yang tidak membawa piring dan gelas plastik.

Pedagang sekolah juga dihimbau untuk menjual jajanan yang sehat dan tidak menggunakan plastik. Jika terpaksa dalam jajanan tersebut dibungkus plastik maka ketika memberikan jajanan kepada siswa, bungkus plastiknya diambil pedagang sekolah dan dikumpulkan di tempat sampah yang ada di kantin. Siswa menerima jajanan di piring dan gelas plastik sudah tidak dibungkus plastik. Setelah selesai makan, piring dan gelas plastik bisa dicuci di sekolah, sekaligus untuk melatih siswa supaya tanggung jawab. Setiap hari siswa membawa kembali piring dan gelas plastik jika ingin jajan di sekolah. Hasil kegiatan sebagai berikut

1. Seluruh siswa membawa piring dan gelas plastik

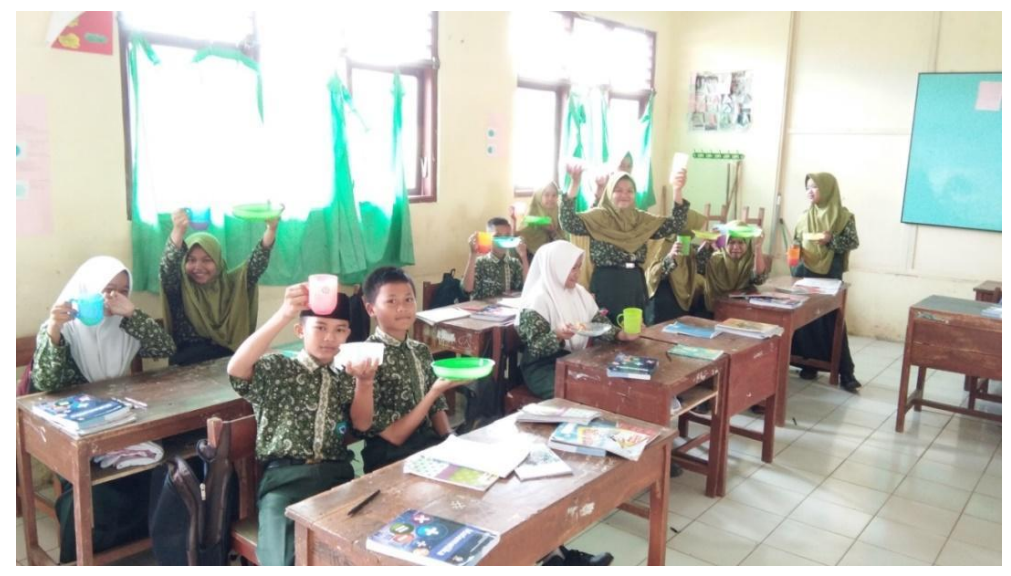

\section{Gambar 2. Peserta Didik makan jajan di dalam kelas dengan PIGELTIK}

Gambar 2, Suasana peserta didik makan jajan di dalam kelas dengan PIGELTIK. Hal ini menjadikan anak lebih teratur karena peserta didik makan sambil duduk. Seteleh makanan dan minuman habis, mereka akan langusng mencuci PIGELTIK nya masing-masing. Sehingga peserta didik memiliki karakter tanggung jawab dan menjaga kebersihan. Dengan menggunakan PIGELTIK maka peserta didik tidak membuang sampah platik bungkus jajan. Sampai - sampai tempat sampah tidak berisi plastik bungkus jajan, hanya berisi beberapa kertas bekas. Langkah ini merupakan cara yang sangat efektif dalam mengurangi sampah.

2. Pedagang sekolah hanya melayani siswa yang membawa piring dan gelas plastik

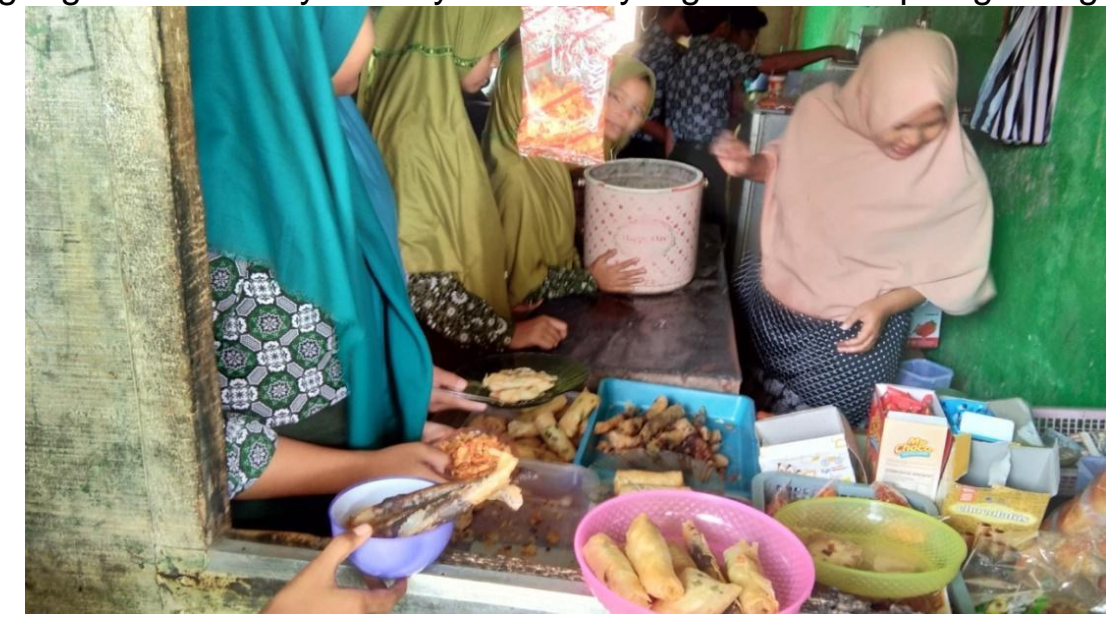

Gambar 3. Pedagang sekolah melayani peserta didik yang jajan dengan PIGELTIK 


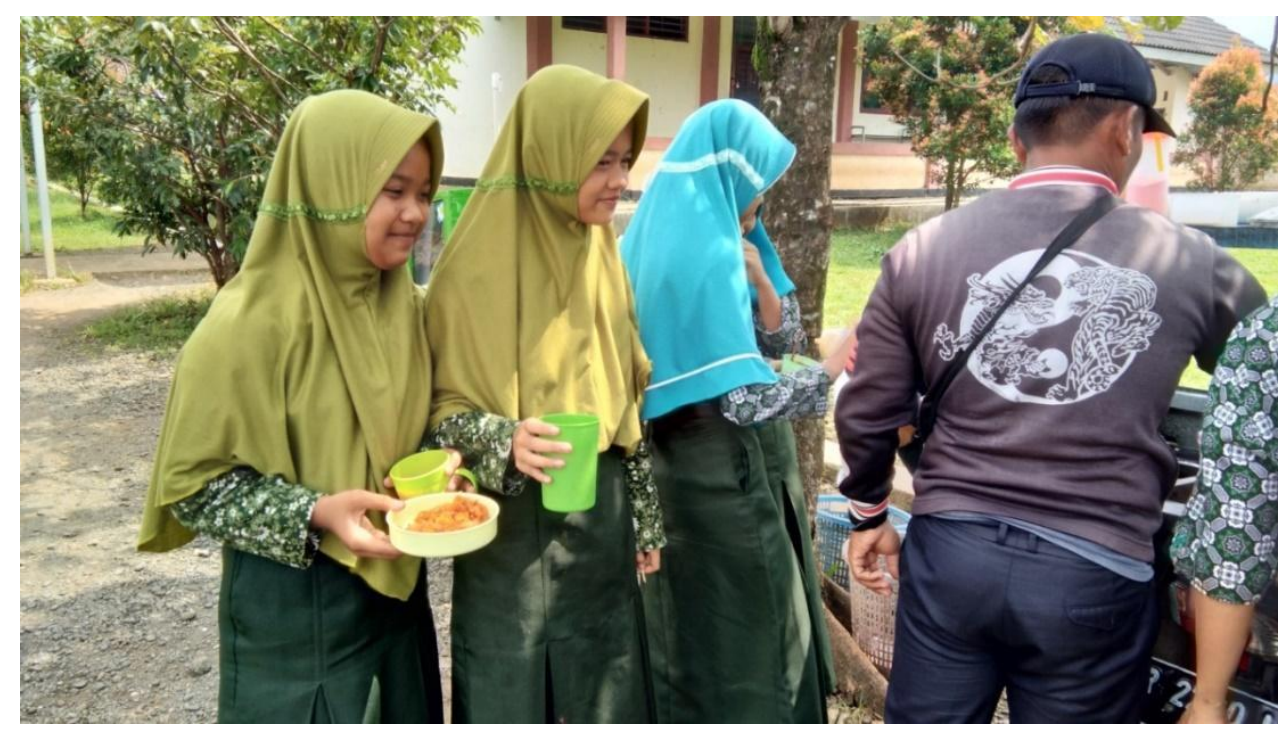

\section{Gambar 4. Pedagang sekolah melayani peserta didik yang jajan dengan PIGELTIK}

Pedagang sekolah melayani peserta didik yang jajan dengan PIGELTIK. Dengan diterapkan strategi PIGELTIK pedagang sekolah merasa senang karena dapat mengurangi biaya untuk membeli palstik. Dalam melayani peserta didik yang jajan juga bisa lebih cepat karena bisa langsung tuang ke piring dan gelas plastik tanpa harus menata plastik yang biasa mereka gunakan. Bagi pedagang minuman, selain mengurangi biaya plastik juga mengurangi biaya sedotan.

3. Sekolah menjadi bersih, indah, sehat dan menyenangkan

a. Sebelum strategi PIGELTIK

1) Peserta didik membuang sampah bukan ditempat sampah

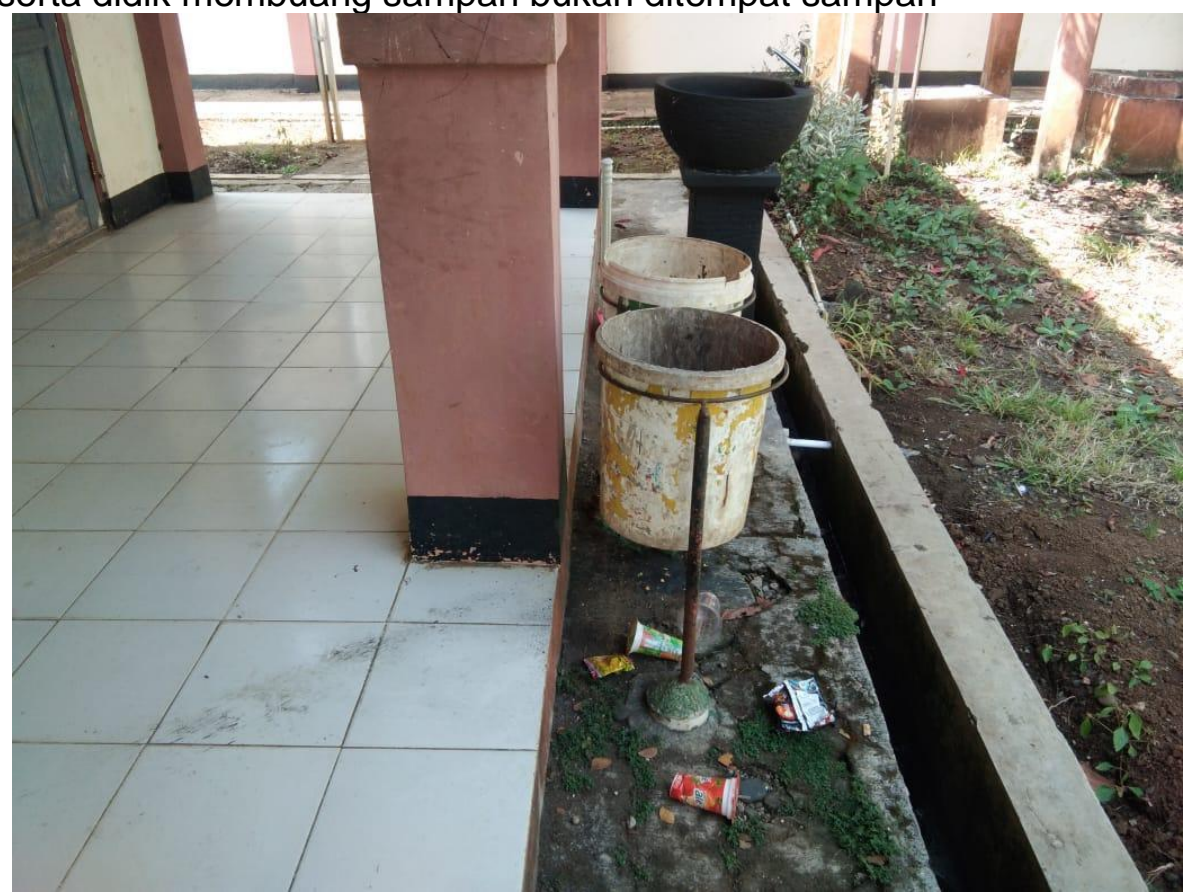

Gambar 5. Siswa membuang sampah bukan di tempat sampah 
Gambar 6, terlihat bahwa peserta didik masih membuang sampah bukan di tempat sampah. Kebiasan tidak baik yaitu membuang sampah seenaknya dan tidak memiliki kepedulian dengan kebersihan lingkungan. Depan ruang kelas terlihat kotor dan dapat menjadi sarang nyamuk atupun bakteri yang dapat berakibat mengganggu kesehatan warga kelas masing-masing.

2) Peserta didik membuang sampah di selokan

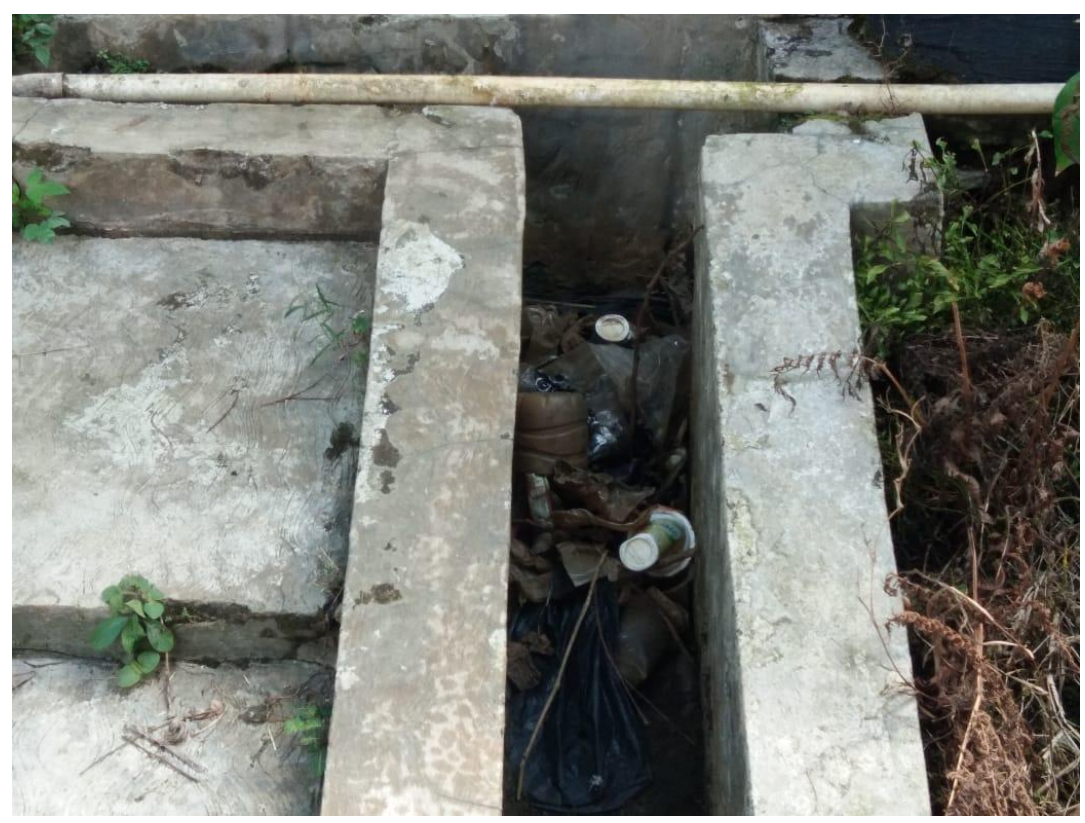

Gambar 6. Peserta didik membuang sampah di selokan

Peserta didik membuang sampah di selokan. Hal inilah yang menyebabkan saluran air menjadi tersumbat. Jika musim hujan maka dapat mengakibatkan banjir dan air keluar meluap dari selokan tersebut. Jika tidak ditangani maka teras ruang kelas akan terendam air dan menjadi kotor sekali. Apalagi sekolah yang memiliki saluran air yang berbentuk gorong-gorong yang jika tersumbat maka akan sulit untuk mengambil sampah dari dalam gorong-gorong tersebut.

3) Peserta didik membuang sampah di lapangan dan di halaman sekolah

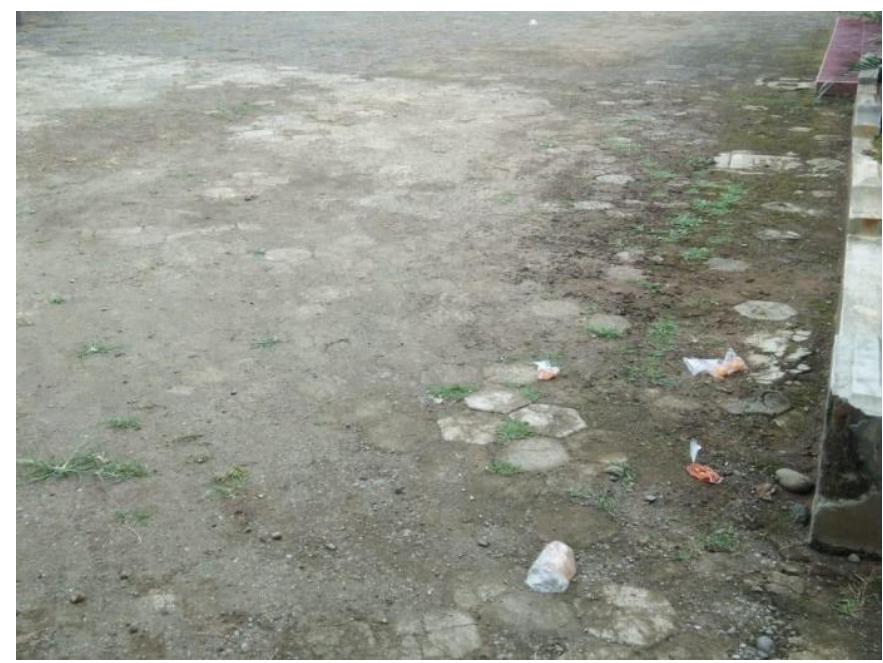

Gambar 7. Peserta didik membuang sampah di halaman sekolah 
Peserta didik membuang sampah di lapangan dan halaman sekolah. Hal ini akan mengurangi keindahan lingkungan sekolah dan terkesan kotor sekali. Ketika upacara bendera maupun olahraga tampak pemandangan sampah yang berserakan. Yang lebih ironis lagi, ketika peserta didik melaksanakan upacara, olahraga ataupun berjalan dengan melihat ada sampah mereka kurang peduli dan enggan untuk mengambil sampah tersebut. Seolah cuek dengan keadaan lingkungan yang banyak sampahnya. Jika warga sekolah memiliki sikap yang sama maka bisa menjadi lautan sampah.

b. Setelah strategi PIGELTIK

1) Peserta didik membuang sampah ditempat sampah

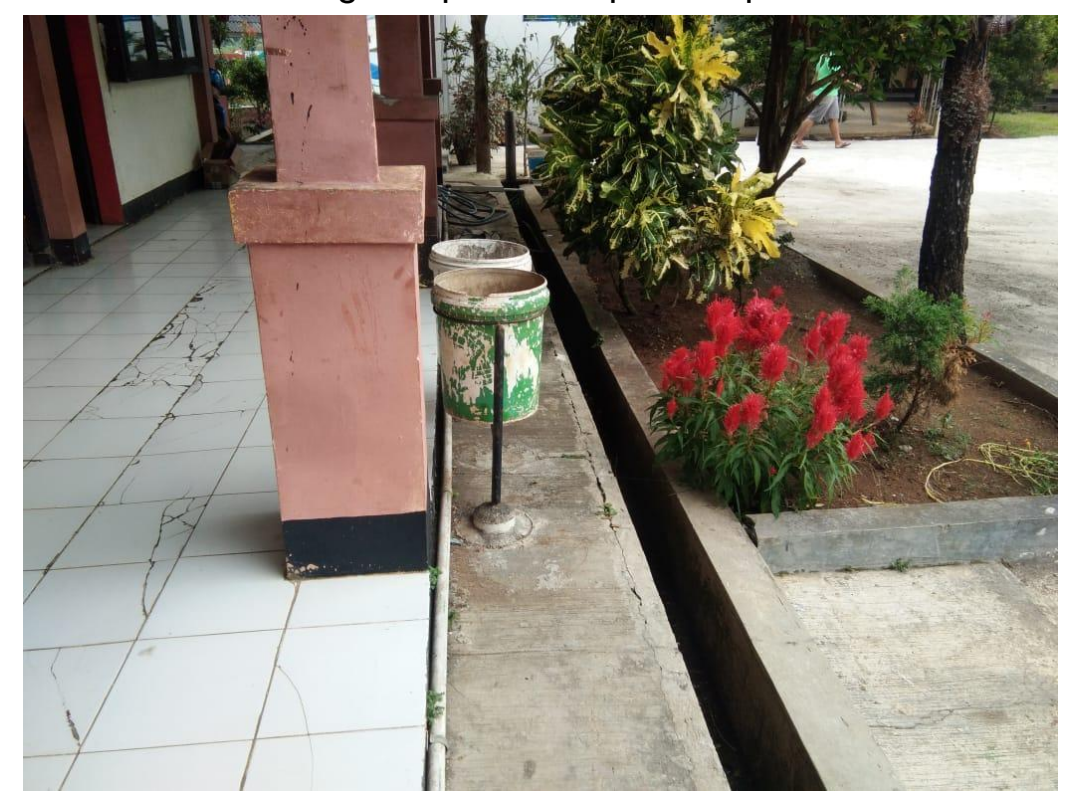

\section{Gambar 8. Peserta didik membuang sampah di tempat sampah}

Peserta didik telah membuang sampah di tempat sampah. Hal ini menunjukkan kesadaran peserta didik untuk membuang sampah meningkat. Sampah-sampah tidak berserakan di depan kelas. Lingkungan kelas menjadi bersih, rapi, indah, nyaman dan menyenangkan. Demikian juga di dalam kelas maupun laci meja sudah bersih dari sampah. Peserta didik menjadi betah dalam mengikuti proses belajar mengajar. Pembelajaran juga semakin menyenangkan.

2) Peserta didik tidak membuang sampah di selokan

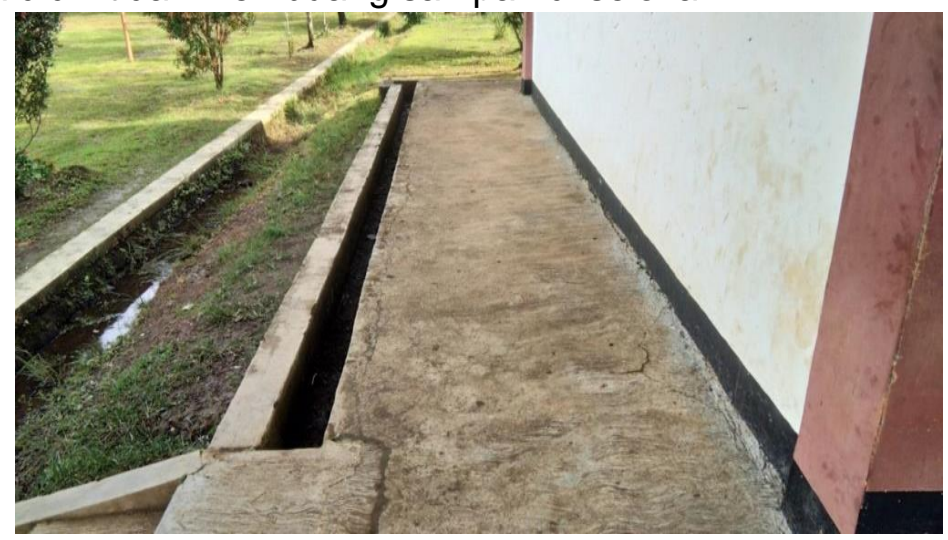

Gambar 9. Peserta didik tidak membuang sampah di selokan 
Peserta didik tidak membuang sampah di selokan. Hal ini membuat saluran air dapat mengalir dengan lancar. Tidak ada sumbatan air dan kelihatan bersih dan indah.

3) Peserta didik tidak membuang sampah di lapangan dan halaman sekolah

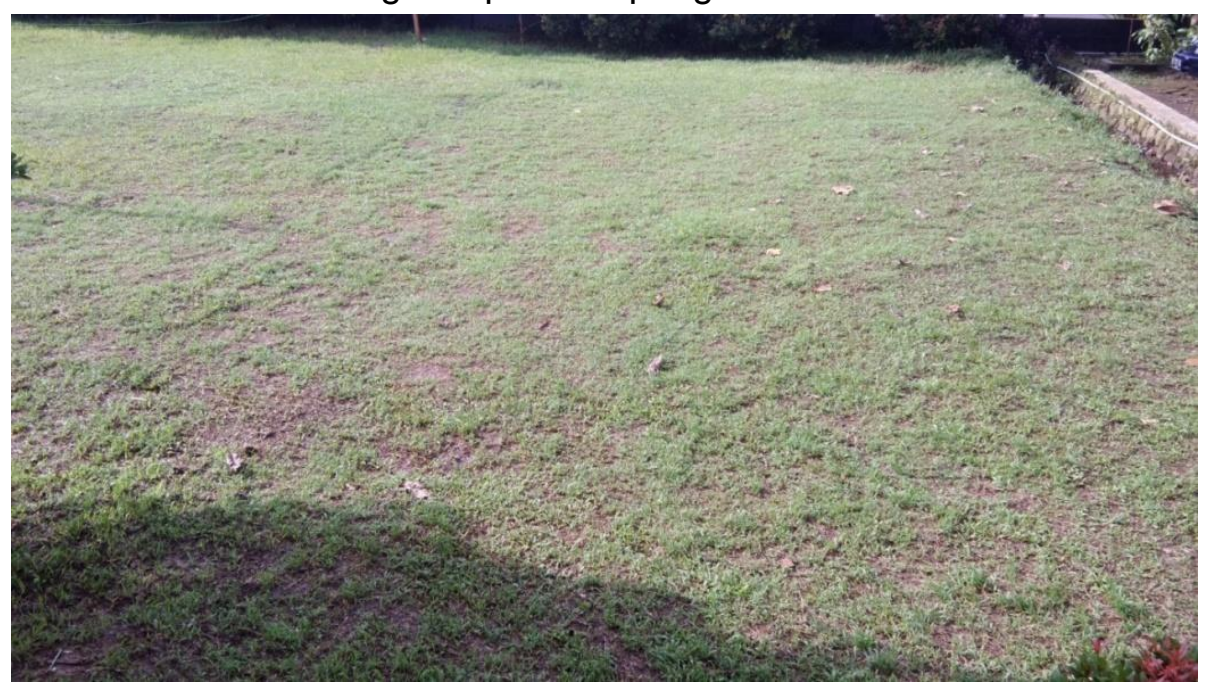

Gambar 10. Peserta didik tidak membuang sampah di lapangan

Peserta didik tidak membuang sampah di lapangan dan halaman sekolah. Lapangan terasa nyaman untuk digunakan upacara maupun olah raga. Halaman sekolah kelihatan bersih dan indah. Hal ini akan memperindah wajah SMP Negeri 4 Bobotsari.

Dengan strategi PIGELTIK maka sikap peduli warga SMP Negeri 4 Bobotsari terhadap lingkungan meningkat. Hal ini merupakan modal dalam mempersiapkan Sekolah Adiwiyata. Pendidikan karakter peserta didik dapat dibentuk dengan membudayakan sikap peduli terhadap lingkungan. Kebersihan lingkungan merupakan tanggung jawab bersama seluruh warga sekolah. Semoga SMP Negeri 4 Bobotsari kedepan dapat menjadi Sekolah Adiwiyata dan menjadi sekolah idaman di masyarakat sekitarnya.

\section{SIMPULAN}

Langkah-langkah strategi PIGELTIK untuk menuju sekolah adiwiyata diantaranya adalah

a. Kepala Sekolah mensosialisasikan kepada seluruh warga sekolah tentang strategi pigeltik dalam amanat upacara bendera

b. Urusan $7 \mathrm{~K}$ bersama wali kelas memerintahkan kepada siswa untuk membawa piring dan gelas plastic.

c. Kepala Sekolah bersama Urusan 7K mengumpulkan para pedagang di sekolah untuk diberikan pengarahan tentang pigeltik dan keharusan menjaga kebersihan sekolah

d. Kepala sekolah memerintahkan kepada wali kelas dan 7K untuk mendata siswa yang memiliki piring dan gelas plastik. Bagi yang sudah memiliki maka dapat membawa piring dan gelas plastik yang sudah ada di rumah, namun jika belum memiliki dapat memesan kepada koperasi sekolah

e. Koperasi sekolah menyediakan piring dan gelas plastik sesuai data siswa yang belum memiliki. Koperasi siswa sifatnya hanya membantu peserta didik dalam melaksanakan program sekolah dan sifatnya tidak wajib membeli di koperasi.

Hasil pelaksanaan strategi PIGELTIK untuk menuju sekolah adiwiyata adalah

a. Seluruh siswa membawa piring dan gelas plastik

b. Pedagang sekolah hanya melayani siswa yang membawa piring dan gelas plastik

c. Sekolah menjadi bersih, indah, sehat dan menyenangkan 
d. Peserta didik membuang sampah ditempat sampah

e. Peserta didik tidak membuang sampah di selokan

f. Peserta didik tidak membuang sampah di lapangan dan halaman sekolah Dengan strategi PIGELTIK maka sikap peduli warga SMP Negeri 4 Bobotsari terhadap lingkungan meningkat. Hal ini merupakan modal dalam mempersiapkan Sekolah Adiwiyata. Pendidikan karakter peserta didik dapat dibentuk dengan membudayakan sikap peduli terhadap lingkungan. Untuk menanamkan pendidikan karakter kepada peserta didik maka sekolah harus membiasakan kegiatan positif sehingga akan memunculkan budaya yang didalamnya termasuk budaya peduli terhadap lingkungan

\section{DAFTAR PUSTAKA}

Nugraha, A., Sutjahjo, S. H., \& Amin, A. A." Analisis Persepsi dan Partisipasi Masyarakat Terhadap Pengelolaan Sampah Rumah Tangga di Jakarta Selatan".Jurnal Pengelolaan Sumberdaya Alam dan Lingkungan (Journal of Natural Resources and Environmental Management), 8(1), (2018):7-14

Ahmad Baihaqi, "Manajemen Strategik dalam Pengembangan Madrasah Adiwiyata di MTs Negeri 6 Ponorogo " Tesis,( Ponorogo: IAIN Ponorogo, 2019)

Robingaenah. "Manajemen Madrasah Berbasis Adiwiyata di Madrasah Aliyah Negeri 1 Cilacap"Tesis (Purwokerto: IAIN Purwokerto, 2018), vii

Peraturan Menteri Lingkungan Hidup Republik Indonesia Nomor 05 Tahun 2013 Tentang Pedoman Pelaksanaan Program Adiwiyata

http://repository.ut.ac.id/4033/1/PKOP4301-M1.pdf diakses tanggal 10 Agustus 2020

https://pengertiandefinisi.com/pengertian-sekolah-dan-fungsi-sekolah/ diakses tanggal 10 Agustus 2020

https://www.gurupendidikan.co.id/pengertian-strategi/ diakses tanggal 13 Agustus 2020 https://www.psikolif.com/pengertian-piring/ diakses tanggal 13 Agustus 2020

https://www.academia.edu/28949865/Pengertian_Gelas_Dan_Kaca diakses tanggal 13 Agustus 2020

https://foresteract.com/plastik/ diakses tanggal 13 Agustus 2020

https://pendidikan.co.id/pengertian-sekolah-fungsi-unsur-beserta-jenjangnya/ diakses tanggal 20 Agustus 2020 